\title{
Taxonomy and morphology of four "ophrys-related" scuticociliates (Protista, Ciliophora, Scuticociliatia), with the description of a new genus, Paramesanophrys gen. nov.
}

\author{
Xuming PAN ${ }^{1}$, Xinpeng FAN ${ }^{2, *}$, Saleh A. AL-FARRAJ ${ }^{3}$, Shan GAO $^{4} \&$ Ying CHEN ${ }^{5, *}$ \\ ${ }^{1,5}$ College of Life Science and Technology, Harbin Normal University, Harbin 150025, China. \\ ${ }^{1,2}$ School of Life Sciences, East China Normal University, Shanghai, 200062, China. \\ ${ }^{3}$ Zoology Department, King Saud University, Riyadh 11451, Saudi Arabia. \\ ${ }^{4}$ Institute of Evolution \& Marine Biodiversity, Ocean University of China, Qingdao 266003, China, \\ and Laboratory for Marine Biology and Biotechnology, Qingdao National Laboratory for Marine \\ Science and Technology, China. \\ "Corresponding authors: xpfan@bio.ecnu.edu.cn (Xinpeng Fan); 1h6666@126.com (Ying Chen) \\ ${ }^{1}$ E-mail: pppppp206@126.com \\ ${ }^{3}$ E-mail: salfarraj@hotmail.com \\ ${ }^{4}$ E-mail: shangao@ouc.edu.cn \\ ${ }^{1}$ urn:1sid:zoobank.org:author:B438F4F6-95CD-4E3F-BD95-527616FC27C3 \\ 2 urn:lsid:zoobank.org:author:AC458497-30FF-411C-8724-D8297B3BE5EA \\ ${ }^{3}$ urn:Isid:zoobank.org:author:BA12A34C-2A08-4493-97DA-0BCCF6B7ED36 \\ ${ }^{4}$ urn:lsid:zoobank.org:author:527DECF1-6523-4213-B33F-1369F8602C02 \\ ${ }^{5}$ urn:Isid:zoobank.org:author:4FB3E509-1D9C-41EA-906A-1F5BCBC6EDD6
}

\begin{abstract}
Generally, "ophrys-related" scuticociliates belong to a specialised group of ciliated protozoa that may act as commensals or pathogens of fishes and crustaceans. In the present study, four "ophrystaxa" scuticociliates, i.e., Paramesanophrys typica gen. et sp. nov., Mesanophrys carcini (Grolière \& Léglise, 1977) Small \& Lynn in Aescht, 2001, Metanophrys sinensis Song \& Wilbert, 2000, and Metanophrys similis Song et al., 2002, were collected from Chinese coastal waters or mariculture ponds and investigated. Paramesanophrys gen. nov. is assigned to the family Orchitophryidae and differs from its other genera mainly by the position of the paroral membrane relative to membranelle $1-3$, i.e., the membrane extends anteriorly to the posterior end of membranelle 3 . The type species $P$. typica gen. et sp. nov., is defined by an elongated body with the posterior end depressed where the caudal cilium is located; 20 or 21 somatic kineties; double-rowed membranelle 1 with eight to ten basal bodies in each kinety; irregularly multi-rowed membranelle 2 and membranelle 3 ; scutica comprising $c$. seven or eight kinetosome pairs; a single macronuclear nodule; and marine habitat. The redescription of the three previously known species can be summarized as follows: 1) improved diagnosis is provided for Metanophrys sinensis Song \& Wilbert, 2000 based on the original description and the present study; 2) some population-dependent characteristics of our new Mesanophrys carcini isolate are presented; 3) Metanophrys similis, collected from the South China Sea, resembles the original Qingdao population.
\end{abstract}


Keywords. Scuticociliates, Paramesanophrys gen. nov., Paramesanophrys typica gen. et sp. nov., Mesanophrys, Metanophrys.

Pan X., Fan X., Al-Farraj S.A., Gao S. \& Chen Y. 2016. Taxonomy and morphology of four "ophrys-related" scuticociliates (Protista, Ciliophora, Scuticociliatia), with the description of a new genus, Paramesanophrys gen. nov. European Journal of Taxonomy 191: 1-18. http://dx.doi.org/10.5852/ejt.2016.191

\section{Introduction}

Ciliates in the subclass Scuticociliatia, commonly found in ecosystems worldwide, exhibit a great biological diversity and play important roles in marine ecosystems (Thompson \& Kaneshiro 1968; Foissner \& Wilbert 1981; Cawthorn et al. 1996; Lynn \& Strüder-Kypke 2005; Fan et al. 2011a, b, 2014; Pan et al. 2013a, b; Castro et al. 2014; Foissner et al. 2014; Zhan et al. 2014). Many of them are common pathogens of fishes and invertebrates and can cause severe disease or even death in economically important aquaculture animals (Pérez-Uz \& Song 1995; Song \& Wilbert 2002; Fan et al. 2009, 2010; Mallo et al. 2014; Ofelio et al. 2014). However, due to their small body size and a high degree of similarity in ciliature, the taxonomy of this group of organisms remains difficult and confusing (Thompson 1964; Agatha et al. 1993; Song 2000; Song \& Wilbert 2000; Pan et al. 2010). Recent investigations in Chinese seas have shown a high diversity of scuticociliates, and the discovery of new

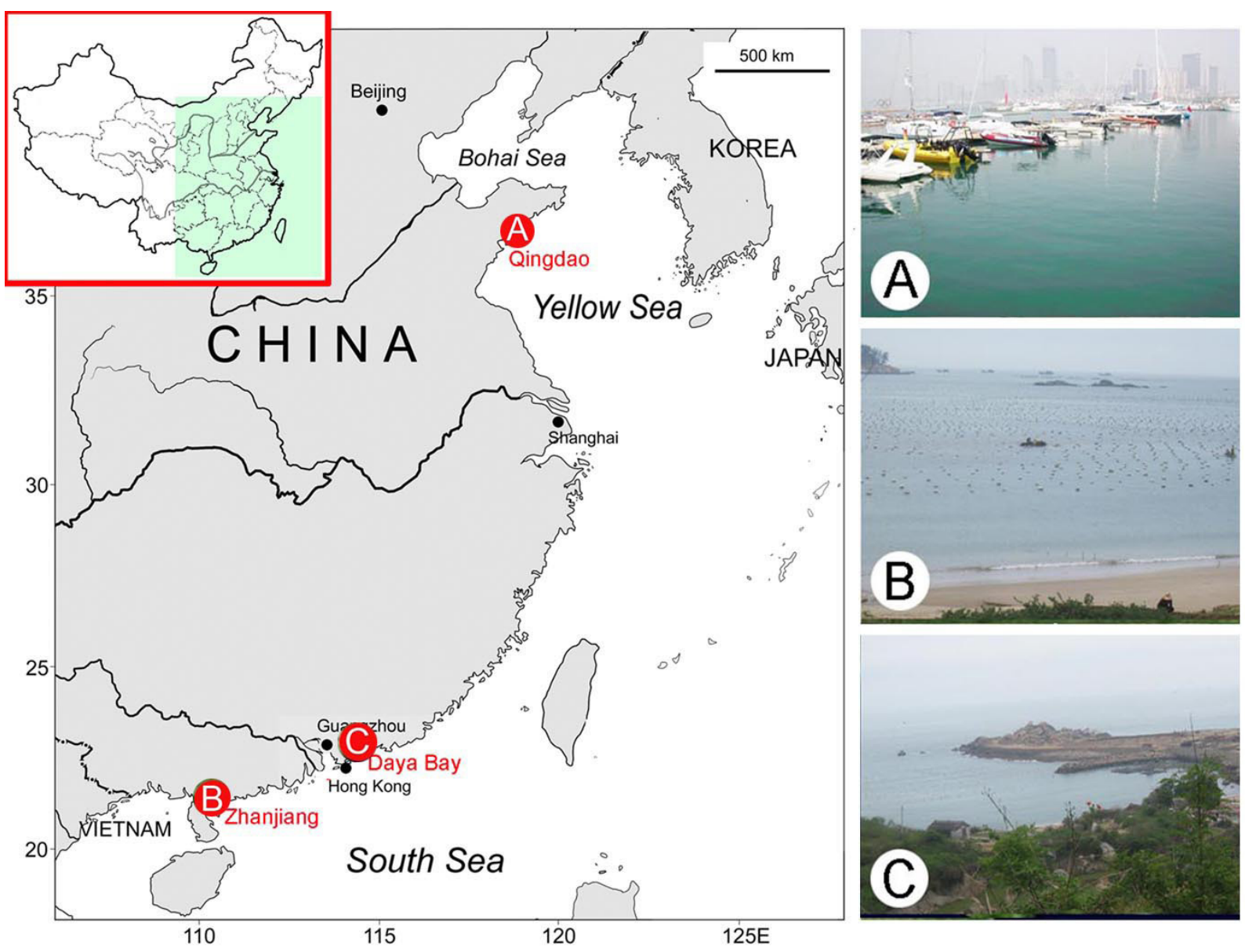

Fig. 1. Sampling sites. A. Coastal waters of the Yellow Sea at Qingdao, Shandong province. B. A coastal mariculture-region in Zhanjiang, Guangdong province. C. Coastal waters of Daya Bay, Guangdong province. 
PAN X. et al., Descriptions of four marine scuticociliates

Table 1. Comparison of collection data for four species.

\begin{tabular}{lcccc}
\hline & $\begin{array}{c}\text { Paramesanophrys } \\
\text { typica gen. et sp. nov. }\end{array}$ & $\begin{array}{c}\text { Mesanophrys } \\
\text { carcini }\end{array}$ & $\begin{array}{c}\text { Metanophrys } \\
\text { similis }\end{array}$ & $\begin{array}{c}\text { Metanophrys } \\
\text { sinensis }\end{array}$ \\
\hline Collecting site & Daya Bay, Guangdong & Qingdao, Shandong & Zhanjiang, Guangdong & Zhanjiang, Guangdong \\
Collecting date & 21 Apr. 2011 & 26 Feb. 2010 & 6 Nov. 2011 & 6 Nov. 2011 \\
Habitat & marine & marine & brackish water & brackish water \\
Temperature $\left({ }^{\circ} \mathrm{C}\right)$ & 19 & 11 & 21 & 20 \\
Salinity $(\% 0)$ & 30 & 31 & 23 & 23 \\
pH & 7.5 & 7.3 & 6.7 & 6.8 \\
Relative abundance & Low & Low & Low & High \\
\hline
\end{tabular}

taxa has highlighted the necessity to conduct further studies on this group (Wang et al. 2008a, b, 2009; Gao et al. 2010, 2012a, b, 2013; Pan et al. 2011, 2015a, b).

The "ophrys-taxa" scuticociliates include species of Mesanophrys Puytorac et al., 1974, Metanophrys Small \& Lynn, 2001 and Paranophrys Thompson \& Berger, 1965. Noticeably, they share many common morphological characteristics, e.g., body usually elongate, oval or cylindrical with a pointed anterior end but no apical plate; cytostome positioned at, or anterior to, the mid-body; buccal apparatus comprising a paroral membrane (PM) and three Parauronema-like membranelles, membranelle 1 (M1) and membranelle 2 (M2) each composed of two or more rows of kinetids. Most species are opportunistic parasites (Noland 1937; Borror 1963; Grolière \& Léglise 1977; Strüder \& Wilbert 1992; Song \& Wilbert 2000; Song et al. 2002, 2003, 2009; Budiño et al. 2011). Among these genera, Metanophrys and Mesanophrys are the most closely related (body slender, with apical plate absent, cytostome in the anterior half of the body and three Parauronema-like membranelles), with their main difference being the position of the PM relative to M2 (PM extending anteriorly to the middle portion of M2 in Metanophrys vs. to the posterior end of M2 in Mesanophrys) (Small \& Lynn 1985; Strüder \& Wilbert 1992; Song \& Wilbert 2000).

In the present study, a new genus, Paramesanophrys gen. nov., is established and detailed morphological information is provided for four scuticociliates, including one new species, Paramesanophrys typica gen. et sp. nov., and three nominal "ophrys" species.

\section{Material and methods}

Paramesanophrys typica gen. et sp. nov. was sampled on 21 Apr. 2011 from the coastal waters of Daya Bay near Huizhou $\left(22^{\circ} 66^{\prime} 23^{\prime \prime} \mathrm{N}, 114^{\circ} 65^{\prime} 09^{\prime \prime}\right.$ E), China (Fig. 1C). Mesanophrys carcini was collected on 26 Feb. 2010 from the coastal waters off Olympic Sailing Center harbour of Qingdao (36 $\left.06^{\prime} 45^{\prime \prime} \mathrm{N}, 120^{\circ} 39^{\prime} 78^{\prime \prime} \mathrm{E}\right)$, China (Fig. 1A). Metanophrys similis and M. sinensis were collected on 6 Nov. 2010 from the surface water of a coastal shrimp-culturing pond off Zhanjiang $\left(21^{\circ} 15^{\prime} 01^{\prime \prime} \mathrm{N}, 110^{\circ} 44^{\prime} 04^{\prime \prime} \mathrm{E}\right)$, China (Fig. 1B). Detailed collection information is given in Table 1. After isolation, cells were maintained in the laboratory as a uniprotistan culture (Pan et al. 2013a, b).

Cells were observed in vivo using an oil immersion objective with brightfield and Nomarski differential interference contrast optics. Mixtures of a saturated mercury dichloride solution and Bouin's fluid were used to fix samples. The protargol silver staining method (Wilbert \& Song 2008; Pan et al. 2013a) was applied to reveal the infraciliature. Measurements were performed at magnifications of 100-1250×. Drawings were produced with the help of a camera lucida. Systematics and terminology are mainly used in accordance with Lynn (2008) and Small \& Lynn (1985). 
We failed to extract DNA from Paramesanophrys typica gen. et sp. nov. due to the low number of specimens of this species. If possible, we will try to acquire sequence data from it in the future.

\title{
Results
}

\author{
Subclass Scuticociliatia Small, 1967 \\ Order Philasterida Small, 1967 \\ Family Orchitophryidae Cépède, 1910 \\ Genus Paramesanophrys gen. nov. \\ urn:Isid:zoobank.org:act:29EF1135-5A4C-4E60-8977-DAEB6EF21370
}

\section{Diagnosis}

Orchitophryidae with cytostome above mid-body; buccal apparatus consisting of three Parauronemalike membranelles; PM with zigzag structure, extending anteriorly to posterior end of M3; M1 composed of two rows of kinetids; scutica comprising basal body pairs arranged in a line parallel to somatic kineties; single caudal cilium.

\section{Type species}

Paramesanophrys typica gen. et sp. nov.

\section{Etymology}

The generic epithet, Paramesanophrys, refers to the similarity of the oral apparatus to that of the genus Mesanophrys.

Paramesanophrys typica gen. et sp. nov. urn:lsid:zoobank.org:act:7B31578B-6C9A-4F80-BAA9-86C9ED9DC735

Figs 2-3, 4A; Table 2

\section{Diagnosis}

Size in vivo about $90-100 \times 25-35 \mu \mathrm{m}$, elongate body, with pointed anterior end and narrowly rounded caudal end; posterior end distinctly depressed where caudal cilium located; buccal field approximately $40 \%$ of body length; 20 or 21 somatic kineties; M1 with 8-10 basal bodies in each kinety; M2 and M3 irregularly multi-rowed; scutica comprising $c$. seven kinetosome pairs; single macronuclear nodule; contractile vacuole caudally positioned; marine habitat.

\section{Etymology}

The epithet of this new species, typica (Greek, the type/typical, gender feminine), refers to the fact that it is the type of the new genus, Paramesanophrys gen. nov.

\section{Type locality and ecological features}

Coastal waters of Daya Bay $\left(22^{\circ} 66^{\prime} 23^{\prime \prime} \mathrm{N}, 114^{\circ} 65^{\prime} 09^{\prime \prime}\right.$ E), Guangdong Province, China, with pH 8.0, salinity $31 \%$ and water temperature about $16^{\circ} \mathrm{C}$.

\section{Type slides}

A protargol slide with the holotype specimen encircled in black ink is deposited in the Laboratory of Protozoology, Ocean University of China (PXM-2011042101). A paratype slide is deposited in the Natural History Museum, London, UK (2016.3.10.1). 


\section{Description}

Size $90-100 \times 25-35 \mu \mathrm{m}$ in vivo, body elongate, spindle-shaped, with pointed anterior end (Figs $2 \mathrm{~A}-\mathrm{B}$, $3 \mathrm{~A}-\mathrm{D})$. Posterior end narrowly rounded and distinctly depressed in middle of caudal margin at bottom of caudal cilium (Figs 2A, 3A, F). Buccal field approximately $40 \%$ of body length; shape of buccal cavity frequently changed from "falcate-shaped" to oval to circular, then conversed (Figs 2C, 3G, I-N). Pellicle slightly indented at bases of cilia (Figs 2F, 3E, H). Extrusomes spindle-shaped, c. 2-4 $\mu \mathrm{m}$ long (Fig. 2F). Cytoplasm colourless to greyish, containing several to many large (c. $5 \mu \mathrm{m}$ across) food vacuoles filled with bacteria, often concentrated in anterior and posterior ends of body (Figs 2A, E, 3E, H). Single ellipsoid to spherical macronucleus, c. $15 \mu \mathrm{m}$ across, no micronucleus observed (Fig. 3R). Contractile vacuole caudally located, approximately $8 \mu \mathrm{m}$ across during diastole, pulsating at intervals of approximately $30 \mathrm{~s}$ (Figs 2A, 3F). Somatic cilia, approximately $10 \mu \mathrm{m}$ long, densely arranged; single caudal cilium approximately $30 \mu \mathrm{m}$ long (Figs 2A, 3E-F). Movement by swimming while rotating about long body axis without pause or by gliding on substrate (Fig. 2D).

Twenty or 21 somatic kineties, extending entire length of body and consisting of dikinetids in most of body and monokinetid in rest of body (Figs 2G-H, 3S). Buccal apparatus (Figs 2I, 3O-Q) consisting of $\mathrm{PM}$ and three Parauronema-like membranelles. M1 composed of two rows of kinetids with $8-10$ basal bodies each (Figs 2I, 3Q). M2 and M3 irregularly multi-rowed. M3 much shorter than M2 (Fig. 3O-Q).


B
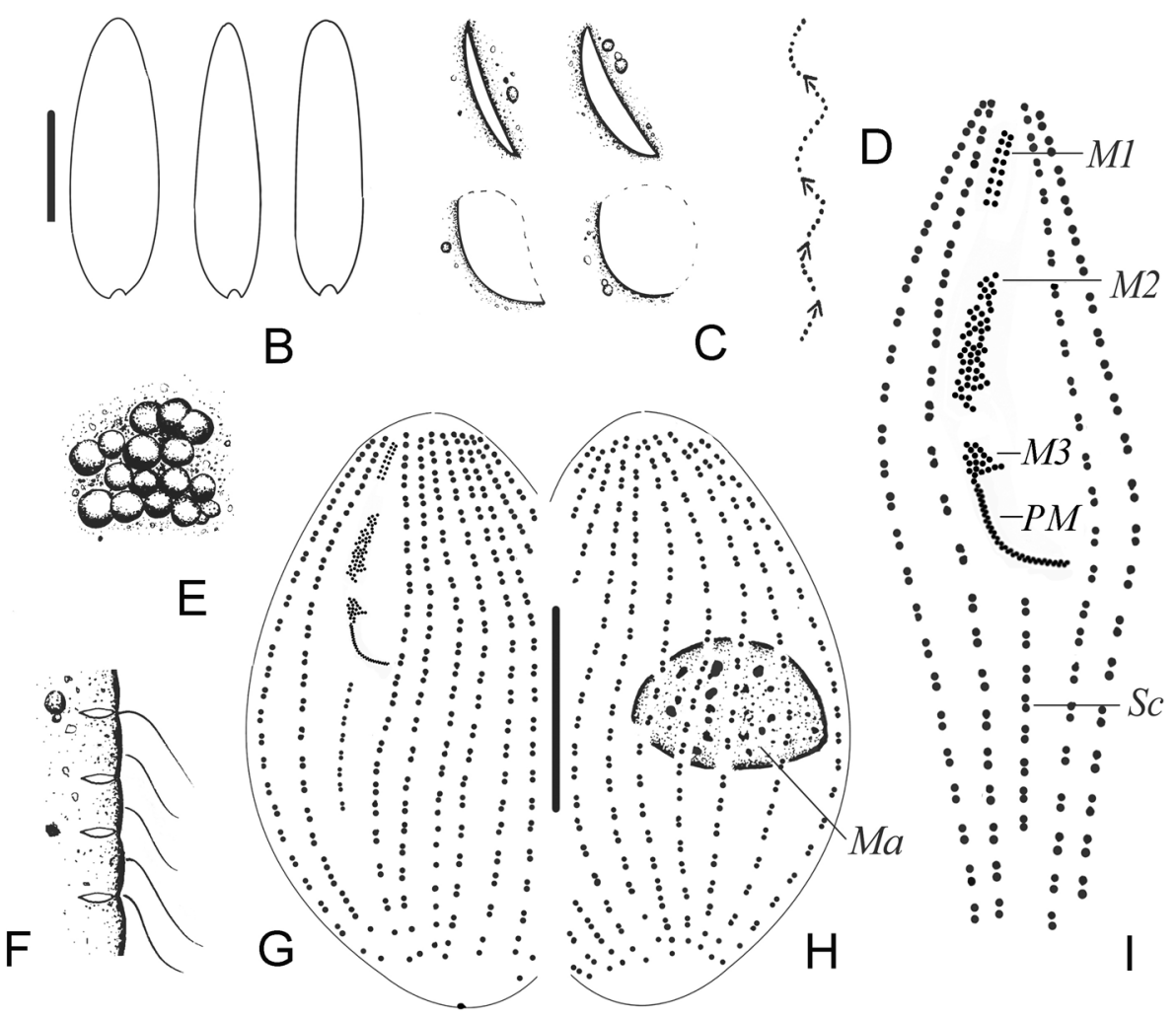

Fig. 2. Paramesanophrys typica gen. et sp. nov., from life (A-F) and after protargol staining $(\mathbf{G}-\mathbf{I})$. A. Ventral view of a representative individual. B. Different body shapes. C. Changing shapes of buccal field of the same individual. D. Movement trace. E. Food granules. F. Part of pellicle, to show extrusomes. G-H. Ventral (G) and dorsal (H) views of the same specimen (holotype), showing infraciliature and nuclear apparatus. I. Detailed structure of the buccal area. Abbreviations: M1-3 $=$ membranelles 1, 2 and 3; $\mathrm{Ma}=$ macronucleus; $\mathrm{PM}=$ paroral membrane; $\mathrm{Sc}=$ scutica. Scale bars: $\mathrm{A}=30 \mu \mathrm{m} ; \mathrm{B}=40 \mu \mathrm{m}$. 
Table 2. Morphometric characterization of Paramesanophrys typica gen. et sp. nov. (Typ), Mesanophrys carcini (Grolière \& Léglise, 1977) Small \& Lynn in Aescht, 2001 (Car), Metanophrys sinensis Song \& Wilbert, 2000 (Sin) and Metanophrys similis Song et al., 2002 (Sim).

\begin{tabular}{|c|c|c|c|c|c|c|c|c|}
\hline Character & Species & Min & Max & Mean & $\mathbf{M}$ & SD & $\mathrm{CV}$ & $\bar{n}$ \\
\hline \multirow[t]{4}{*}{ Body length $(\mu \mathrm{m})$} & Typ & 96 & 113 & 105.1 & 107 & 9.7 & 9.2 & 20 \\
\hline & Car & 42 & 74 & 56.9 & 60 & 6.7 & 12.1 & 25 \\
\hline & Sin & 33 & 59 & 43.6 & 41 & 14.4 & 27.1 & 23 \\
\hline & Sim & 47 & 75 & 61.7 & 57 & 5.2 & 16.4 & 23 \\
\hline \multirow[t]{4}{*}{ Body width $(\mu \mathrm{m})$} & Typ & 32 & 38 & 34.7 & 35 & 5.8 & 3.9 & 20 \\
\hline & Car & 40 & 50 & 43.1 & 43 & 5.8 & 11.7 & 25 \\
\hline & $\operatorname{Sin}$ & 16 & 24 & 19.9 & 20 & 1.9 & 9.9 & 23 \\
\hline & Sim & 35 & 52 & 44.7 & 45 & 7.3 & 17.6 & 23 \\
\hline \multirow[t]{4}{*}{ Number of somatic kineties } & Typ & 20 & 21 & 20.4 & 20 & 1.3 & 6.1 & 18 \\
\hline & Car & 10 & 11 & 10.6 & 11 & 0.8 & 7.8 & 22 \\
\hline & $\operatorname{Sin}$ & 10 & 11 & 10.1 & 10 & 0.6 & 5.9 & 20 \\
\hline & Sim & 17 & 17 & 17 & 17 & 3.5 & 20.6 & 21 \\
\hline \multirow[t]{4}{*}{ Length of buccal field $(\mu \mathrm{m})$} & Typ & 37 & 41 & 38.4 & 39 & 3.7 & 9.8 & 18 \\
\hline & Car & 21 & 24 & 23.1 & 23 & 1.2 & 9.4 & 25 \\
\hline & $\operatorname{Sin}$ & 15 & 26 & 19.6 & 19 & 1.6 & 8.7 & 23 \\
\hline & Sim & 34 & 43 & 37.3 & 38 & 1.3 & 3.4 & 19 \\
\hline \multirow[t]{4}{*}{ Macronucleus, length $(\mu \mathrm{m})$} & Typ & 13 & 16 & 14.7 & 15 & 2.8 & 10.5 & 18 \\
\hline & Car & 10 & 14 & 12.8 & 12 & 1.5 & 12.6 & 24 \\
\hline & $\operatorname{Sin}$ & 5 & 6 & 5.7 & 6 & 0.3 & 5.8 & 21 \\
\hline & Sim & 8 & 11 & 9.5 & 9 & 1.9 & 21.6 & 22 \\
\hline \multirow[t]{4}{*}{ Macronucleus, width $(\mu \mathrm{m})$} & Typ & 12 & 15 & 13.4 & 13 & 1.4 & 10.9 & 18 \\
\hline & Car & 11 & 13 & 12.1 & 12 & 0.8 & 6.8 & 24 \\
\hline & $\operatorname{Sin}$ & 6 & 7 & 6.3 & 6 & 1.3 & 20.4 & 21 \\
\hline & Sim & 7 & 10 & 8.6 & 9 & 0.4 & 2.8 & 22 \\
\hline \multirow[t]{4}{*}{ Number of basal bodies in somatic kinety $1^{*}$} & Typ & 22 & 24 & 23.2 & 23 & 1.1 & 4.8 & 17 \\
\hline & Car & 35 & 40 & 37.4 & 37 & 4.6 & 9.9 & 24 \\
\hline & Sin & 32 & 36 & 33.9 & 34 & 8.1 & 24.4 & 20 \\
\hline & Sim & 23 & 26 & 24.1 & 24 & 4.9 & 2.1 & 22 \\
\hline \multirow[t]{4}{*}{ Number of basal bodies in membranelle 1} & Typ & 8 & 10 & 8.6 & 9 & 1.2 & 12.4 & 14 \\
\hline & Car & 7 & 9 & 8.0 & 8 & 0.4 & 5.0 & 19 \\
\hline & $\operatorname{Sin}$ & 7 & 10 & 8.4 & 8 & 1.3 & 16.6 & 15 \\
\hline & Sim & 6 & 6 & 6.0 & 6 & 0 & 0 & 14 \\
\hline \multirow[t]{4}{*}{ Number of scutia pairs } & Typ & 7 & 8 & 7.4 & 7 & 0.6 & 8.5 & 14 \\
\hline & Car & 4 & 4 & 4.0 & 4 & 0 & 0 & 19 \\
\hline & $\operatorname{Sin}$ & 4 & 5 & 4.4 & 4 & 0.2 & 5.2 & 15 \\
\hline & $\operatorname{Sim}$ & 5 & 7 & 6.1 & 6 & 0.3 & 5.1 & 14 \\
\hline
\end{tabular}

Abbreviations: $\mathrm{CV}=$ coefficient of variation in $\% ; \mathrm{M}=$ median; Max = maximum; Mean = arithmetic mean; Min $=$ minimum; $\mathrm{n}=$ number of individuals examined; $\mathrm{SD}=$ standard deviation.

* Basal body pairs counted as single units. 
PM with paired basal bodies organized in zigzag pattern, extending anteriorly to posterior end of M3 (Figs 2G, I, 3O, Q). Scutica located at posterior end of PM, comprising $c$. seven or eight kinetosome pairs aligned in line parallel to somatic kineties (Figs 2G, I).

Mesanophrys carcini (Grolière \& Léglise, 1977) Small \& Lynn in Aescht, 2001

Figs 4B, 5; Table 2

Small \& Lynn in Aescht (2001) did not formally combine this species with Mesanophrys Small \& Lynn in Aescht, 2001. However, since they fixed it as the type species, they automatically produced the combination.

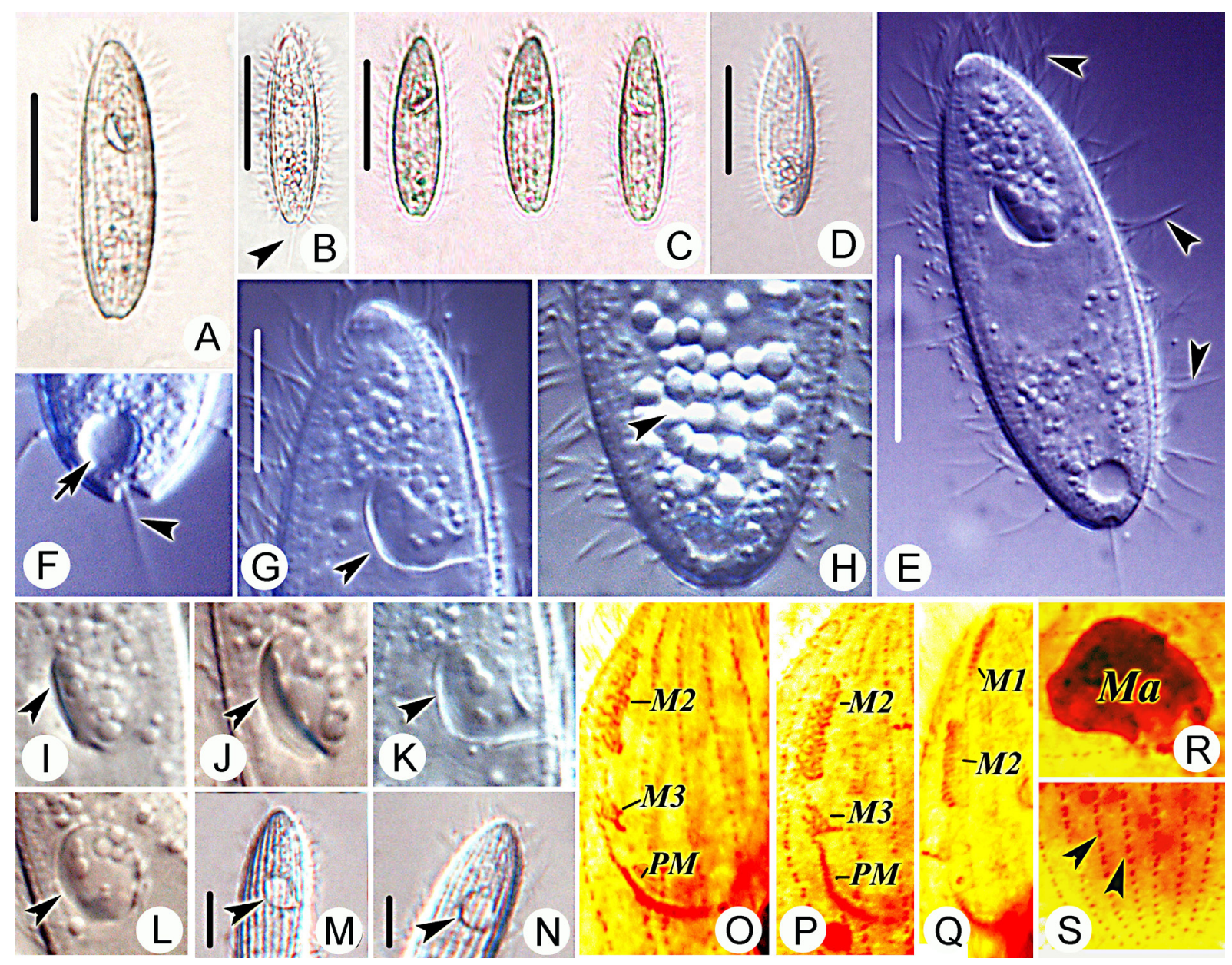

Fig. 3. Paramesanophrys typica gen. et sp. nov., from life (A-N) and after protargol staining $(\mathbf{O}-\mathbf{S})$. A. Ventral view of a representative individual. B-E. Different individuals; arrowhead in B shows caudal cilium, arrowheads in E mark somatic cilia. F. Posterior region of cell; arrow shows contractile vacuole and arrowhead marks caudal cilium. G. Anterior region of cell; arrowhead marks buccal region. H. Ventral view, showing food vacuoles (arrowhead). I-N. Ventral views, to show various shapes of buccal regions (arrowheads). O-Q. Detailed infraciliature of buccal area (P from holotype). R. Macronucleus. S. Posterior region; arrowheads show dikinetids of somatic kineties. Abbreviations: M1-3 = membranelles 1, 2 and 3; $\mathrm{Ma}=$ macronucleus; $\mathrm{PM}=$ paroral membrane. Scale bars: $\mathrm{A}, \mathrm{E}=40 \mu \mathrm{m}$; $\mathrm{B}-\mathrm{D}=70 \mu \mathrm{m} ; \mathrm{G}, \mathrm{M}-\mathrm{N}=10 \mu \mathrm{m}$. 
Some characteristics, e.g., a larger body size and fewer somatic kineties, were found in the Qingdao population. Hence, a description of the Qingdao population as well as a comparison between different populations are supplied.
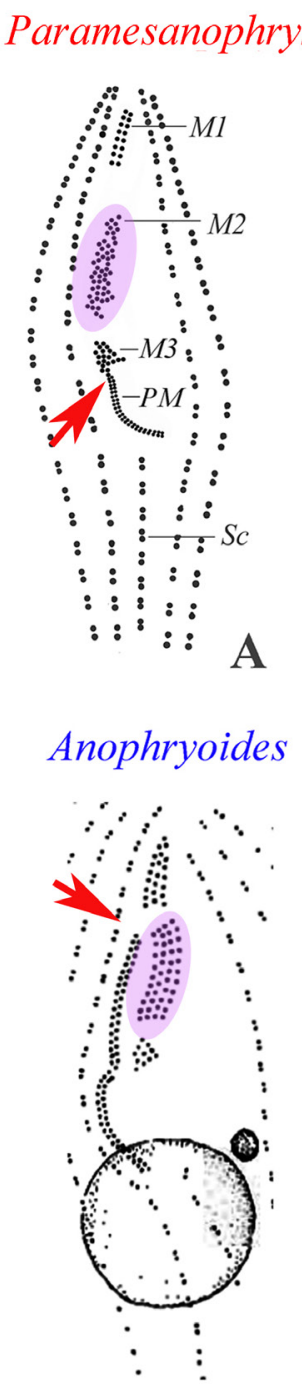


B

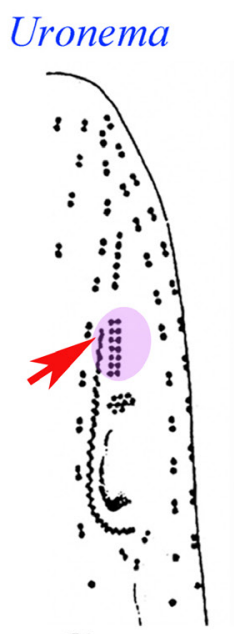

C

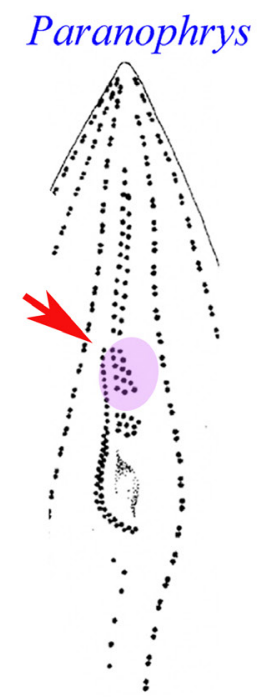

H

\section{Uronemella \\ Metanophrys}
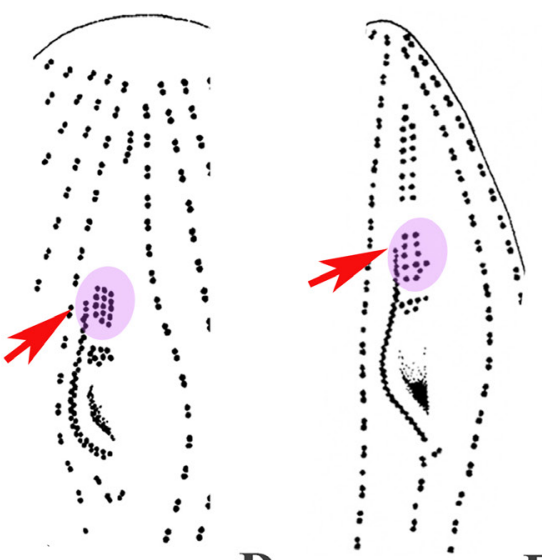

D

$\mathbf{E}$

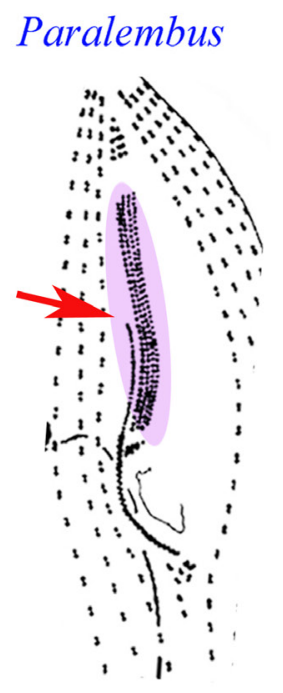

Cohnilembus

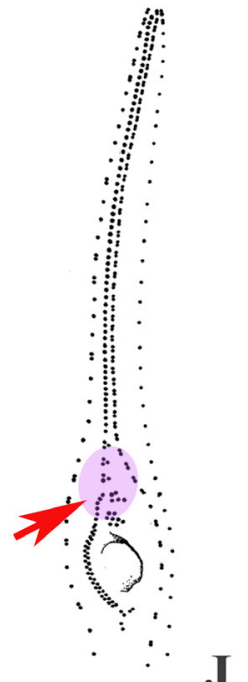

Fig. 4. Comparisons among different buccal apparatus patterns of Paramesanophrys gen. nov. and some related genera; arrows in A-J show different positions to which PM extends anteriorly and highlighted structures in A-J mark M2. A. Paramesanophrys typica gen. et sp. nov. (from the present work). B. Mesanophrys carcini (Grolière \& Léglise, 1977) Small \& Lynn in Aescht, 2001 (from Song \& Wilbert 2000). C. Uronema marinum Dujardin, 1841 (from Song et al. 2009). D. Uronemella filificum (Kahl, 1931) Song \& Wilbert, 2002 (from Song \& Wilbert 2002). E. Metanophrys sinensis Song \& Wilbert, 2000 (from Song \& Wilbert 2000). F. Anophryoides haemophila Cawthorn et al., 1996 (from Cawthorn et al. 1996). G. Philasterides armatalis Song, 2000 (from Song 2000). H. Paranophrys marina Thompson \& Berger, 1965 (from Song et al. 2002). I. Paralembus digitiformis Kahl, 1931 (from Song \& Wilbert 2000). J. Cohnilembus verminus (Müller, 1786) Kahl, 1933 (from Song 2000). Abbreviations: M1-3 = membranelles 1, 2 and 3; $\mathrm{PM}=$ paroral membrane; $\mathrm{Sc}=$ scutica. 


\section{Description of Qingdao population}

Body size 45-65 $\times 15-25 \mu \mathrm{m}$ in vivo, spindle-shaped to long fusiform, with pointed anterior end and narrowly rounded caudal end (Fig. 5A-C). Body shape variable, likely due to nutritional conditions or stage in life cycle: from slender, spindle-like to pyriform (Fig. 5C-D). Buccal field short and narrow, with length of about $30 \%$ of body (Fig. 5B). Somatic cilia densely arranged and about $6-8 \mu \mathrm{m}$ long (Fig. 5B). Pellicle thin and smooth, with no distinguishable extrusomes. Cytoplasm colourless to slightly greyish, containing several to many differently-sized $(3-5 \mu \mathrm{m})$ refringent granules (Fig. 5A, D). Single caudal cilium about $15 \mu \mathrm{m}$ in length (Fig. 5B, arrow) and one large, spherical, centrally located macronucleus; one micronucleus closely associated with macronucleus. Contractile vacuole small ( $5 \mu \mathrm{m}$ across), terminally positioned and pulsating at intervals of approximately $30 \mathrm{~s} \mathrm{(Fig.} \mathrm{5A,} \mathrm{arrow).}$ Movement by continuous swimming in water without pause or gliding slowly on substrate.

Ten or 11 somatic kineties, consisting of dikinetids in anterior two-thirds and monokinetid in posterior third of body (Fig. 5G, arrow). M1 slightly separated from apex, composed of two rows of kinetids with
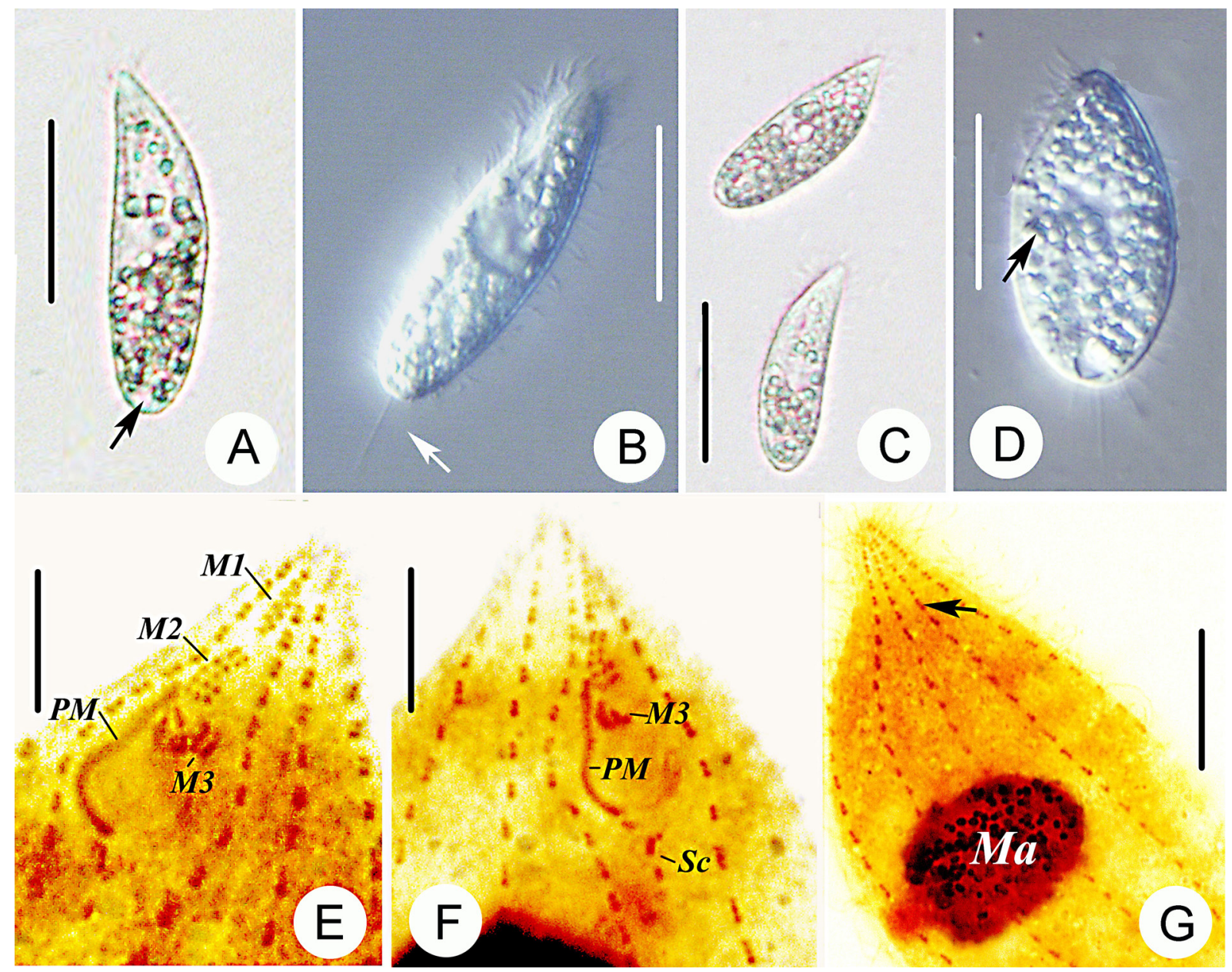

Fig. 5. Mesanophrys carcini Small \& Lynn in Aescht, 2001, in vivo (A-D) and after protargol staining (E-G). A. Ventral view of a representative individual; arrow shows contractile vacuole. B-D. Ventral views of four individuals; arrow in B shows caudal cilium and arrow in D marks food vacuole. E-F. Ventral views, detailed structure of buccal area. G. Dorsal view; arrow indicates somatic kinety. Abbreviations: M1-3 = membranelles 1, 2 and 3; Ma = macronucleus; $\mathrm{PM}=$ paroral membrane; $\mathrm{Sc}=$ scutica. Scale bars: $\mathrm{A}-\mathrm{D}=30 \mu \mathrm{m} ; \mathrm{E}-\mathrm{G}=5 \mu \mathrm{m}$. 
7-9 basal bodies each (Fig. 5E-F). M2 composed of five or six longitudinal rows, each containing about 6-8 basal bodies (Fig. 5E-F). M3 located close to M2, much shorter than M2 and composed of three short, irregularly arranged rows of kinetosomes (Fig. 5E-F). PM extending anteriorly to posterior end of M2. Scutica Y-shaped, with $c$. four pairs of kinetosomes (Fig. 5E-F).

\section{Ecological features}

Salinity $32 \%$, pH 7.9 and water temperature about $11^{\circ} \mathrm{C}$.

Metanophrys sinensis Song \& Wilbert, 2000

Figs 4E, 6; Table 2

This species was described by Song \& Wilbert (2000) in detail based on their Qingdao population. In the current work, it is reported for the first time from South China Sea. An improved diagnosis is provided herein based on all these data; the improved parts are highlighted in bold.

\section{Improved diagnosis}

Slender to elongated oval body shape; in vivo about $25-50 \times 10-20 \mu \mathrm{m}$ with pointed anterior end; buccal field about $\mathbf{3 0 \%}-\mathbf{5 0 \%}$ of body length; mostly ten somatic kineties, of which somatic kinety 1 consists of c. 35 basal pairs; M1 composed of two rows, each with 7-10 kinetosomes, longer than M2; two-rowed M2; contractile vacuole pore located near posterior end of kinety 2; extrusomes present; marine habitat.

\section{Description of Zhanjiang population}

Body $25-30 \times 10-15 \mu \mathrm{m}$ in vivo, usually elongate-oval in outline, with anterior end distinctly pointed and posterior rounded (Fig. 6A-B). Body asymmetrical in outline when viewed ventrally, with anterior end slightly curved sideways (Fig. 6A-B). Ventral side almost straight, while dorsal side convex. Buccal field $2 / 5$ to $1 / 2$ of body length, with cytostome located anterior to equatorial plane of body (Fig. 6C). Cilia densely packed, about 7-8 $\mu \mathrm{m}$ long. Caudal cilium about $15 \mu \mathrm{m}$ in length (Fig. 6B). Pellicle thin and slightly notched, with extrusomes about 2-3 $\mu \mathrm{m}$ long and dense beneath cortex (Fig. 6D). Endoplasm colourless to greyish, containing several food vacuoles and bar- or dumbbell-like crystals, which are usually $3 \mu \mathrm{m}$ long and located in anterior and posterior regions of body (Fig. 6A-B, G). One large round to oval macronucleus approximately centrally located, with many small, irregularly shaped nucleoli on surface. Contractile vacuole about $5 \mu \mathrm{m}$ in diameter and caudally positioned near ventral side (Fig. 6B). Movement with no special features, including swimming moderately fast, sometimes continuously swimming in water without pause.

Ten somatic kineties arranged longitudinally, and dikinetids about $3 / 4$ of length of each in anterior part (Fig. 6J). Buccal apparatus consists of three Parauronema-like membranelles (Fig. 6E-F). M1 slightly below apex and composed of two rows of kinetids with 7-10 basal bodies each, and longer than M2. M2 two-rowed, containing about five basal bodies in each row. M3 located close to M2, normally with three short, obliquely arranged rows of basal bodies. Scutica Y-shaped, with several pairs of kinetosomes (Fig. 6I). Silverline system in quadrangular mesh-pattern (Fig. 6H). Contractile vacuole pore located near posterior end of kinety 2 .

\section{Ecological features}

Salinity $21 \%$, pH 7.3 and water temperature $26^{\circ} \mathrm{C}$. 
Metanophrys similis Song et al., 2002

Fig. 7; Table 2

This species is reported for the first time from the South China Sea. The morphological and behavioural characteristics of the Zhanjiang population closely resemble those of the Qingdao population; therefore, only the morphometric characterisation and important features are supplied.



Fig. 6. Metanophrys sinensis Song \& Wilbert, 2000, in vivo (A-D, G) and after protargol (E-F, I-J) or silver nitrate (H) staining. A. Ventral view of a typical individual. B. Ventral view of another individual; arrowheads mark somatic cilia. C. Ventral view; arrowhead exhibits buccal field. D. Notched pellicle (arrowhead). E. Detailed structure of buccal area. F. Individual in morphogenesis, to show buccal apparatus. G. Ventral view, showing bar-shaped crystal (arrowhead). H. Detail of somatic kinetids. I. Dikinetids of scutica (arrowheads). J. Posterior region; arrowheads show monokinetids of somatic kineties. Abbreviations: M1-3 = membranelles 1, 2 and 3; PM = paroral membrane. Scale bars: $\mathrm{A}-\mathrm{B}=15 \mu \mathrm{m}$. 


\section{Description of Zhanjiang population}

Body in vivo about 35-40 $\times 20-25 \mu \mathrm{m}$, plump pyriform, tapering anteriorly and rounded posteriorly, and no apical plate formed (Fig. 7A-C). Ventral side almost straight, while dorsal side slightly convex (Fig. 7A). Length: width ratio approximately $2: 1$ (Fig. 7A-C). Buccal field occupies about $40 \%$ of total body length, with buccal cilia about 5-8 $\mu \mathrm{m}$ in length. Pellicle thick and strongly notched. Somatic cilia about 7-8 $\mu \mathrm{m}$ long and densely arranged (Fig. 7D, arrowheads). Single caudal cilium about $15 \mu \mathrm{m}$ in length (Fig. 7F). Extrusomes, about $2 \mu \mathrm{m}$ in length, arranged in rows between somatic kineties. Endoplasm colourless to greyish and contains abundant food vacuoles (Fig. 7E). One large, spherical to ovoid macronucleus centrally located (Fig. 7C, J). Contractile vacuole about $5 \mu \mathrm{m}$ in diameter and caudally positioned near ventral side (Fig. 7A).



Fig. 7. Metanophrys similis Song et al., 2002, in vivo (A-F) and after protargol staining (G-J). A. Ventral view of a typical individual. B-D. Ventral views of three individuals; arrowheads in D mark somatic cilia. E. Food vacuole (arrow). F. Posterior region; arrow shows caudal cilium. G, I. Ventral views, to show detailed structure of the buccal area. H. Dorsal view; arrow shows monokinetids, arrowhead marks dikinetids. J. Macronucleus. Abbreviations: M1-3 = membranelles 1, 2 and 3; Ma = macronucleus; $\mathrm{PM}=$ paroral membrane. Scale bars: $\mathrm{A}-\mathrm{D}=30 \mu \mathrm{m}$. 
Locomotion by swimming moderately fast, sometimes continuously without pause, or by crawling on substrates.

Twelve somatic kineties with dikinetids arranged in approximately anterior half of each row and monokinetids positioned posteriorly (Fig. $7 \mathrm{H}$ ). M1 positioned near apex and comprised of three longitudinal rows of kinetids with six basal bodies each (Fig. 7G, I). M2 three-rowed, as long as M1 and also composed of about six basal bodies in each longitudinal row (Fig. 7G, I). M3 located close to M2 and normally comprised of three short, parallel arranged rows of basal bodies (Fig. 7G, I). PM extends to about anterior third of body (Fig. 7G). Scutica, with about 5-7 basal bodies, arranged in long line.

\section{Ecological features}

Salinity $21 \%$, $\mathrm{pH} 7.3$ and water temperature $26^{\circ} \mathrm{C}$.

\section{Discussion}

\section{About Paramesanophrys gen. nov. and P. typica gen. et sp. nov.}

The family Orchitophryidae is characterised as follows: small- to medium-sized body; ovoid-shaped; caudal cilium often present; oral region in anterior $1 / 3$ to $1 / 2$ of body; scutica aligned along midventral postoral region; bacterivorous and histophagous; marine habitats, always as facultative parasites of crustaceans, asteroids, fish and free-swimming (Lynn 2008). Paramesanophrys gen. nov. should be assigned to Orchitophyridae based on its morphological characters and habitat.

Hitherto, five genera have been assigned to Orchitophryidae according to Lynn (2008), namely Anophryoides de Puytorac \& Grolière, 1979, Mesanophrys Small \& Lynn in Aescht, 2001, Metanophrys Puytorac et al., 1974, Orchitophrya Cépède, 1907 and Paranophrys Thompson \& Berger, 1965. Compared with these related genera, Paramesanophrys gen. nov. has a unique oral apparatus, with the PM extending anteriorly to the posterior end of M3 (vs. PM extending anteriorly to the anterior end/ middle portion/posterior end of M2; Fig. 4) (Small \& Lynn 1985; Strüder \& Wilbert 1992; Cawthorn et al. 1996; Song \& Wilbert 2000).

Besides having a unique Paramesanophrys-type PM, Paramesanophrys typica gen et sp. nov. also has the scutica comprising $c$. seven or eight kinetosome pairs aligned in a line parallel to the somatic kineties and a conspicuous pellicle depression in the middle of caudal margin. This combination of features clearly separates it from all known scuticociliates at the species level.

\section{Mesanophrys carcini (Grolière \& Léglise, 1977) Small \& Lynn in Aescht, 2001}

The main characteristics that aid in identifying this species are the slender body, short buccal field, oral apparatus and somatic infraciliature (Song \& Wilbert 2000). The characteristics of the Qingdao population are different from those of the population reported by Song \& Wilbert (2000) in having a larger body size (on average $55 \times 20 \mu \mathrm{m} v \mathrm{~s} .40 \times 12 \mu \mathrm{m}$ ) and a variable number of somatic kineties (10 or 11 vs. constantly 11; Table 3 ). These variations are considered population-dependent (Song \& Wilbert 2000).

\section{Metanophrys sinensis Song \& Wilbert, 2000}

Our population is virtually identical to the two Qingdao populations (Song \& Wilbert 2000; Ma \& Song 2003), that is, they agree in body size and shape, habitat, infraciliature, silverline system and marine habitat, except the proportion of buccal field length to body length (40-50\% in the present study vs. ca. $30-40 \%$ in the previous studies) and the presence of extrusomes (vs. not observed in previous descriptions) (Song \& Wilbert 2000; Ma \& Song 2003; Table 3). Nevertheless, it is believed that they are conspecific because of their close similarity in other living characteristics and infraciliature. 
Table 3. Morphometrical comparison of known ophrys-species populations. Abbreviations: QD, Qingdao or Qingdao population; ZJ, Zhanjiang or Zhanjiang population.

\begin{tabular}{|c|c|c|c|c|c|c|c|}
\hline & $\begin{array}{c}\text { Mesanophrys } \\
\text { carcini }\end{array}$ & $\begin{array}{c}\text { Mesanophrys } \\
\text { carcini QD }\end{array}$ & $\begin{array}{l}\text { Metanophrys } \\
\text { similis }\end{array}$ & $\begin{array}{c}\text { Metanophrys } \\
\text { similis ZJ }\end{array}$ & $\begin{array}{l}\text { Metanophrys } \\
\text { sinensis }\end{array}$ & $\begin{array}{c}\text { Metanophrys } \\
\text { sinensis QD }\end{array}$ & $\begin{array}{c}\text { Metanophrys } \\
\text { sinensis ZJ }\end{array}$ \\
\hline Sample location & $\begin{array}{l}\text { shrimp culture } \\
\text { pond, QD }\end{array}$ & $\begin{array}{c}\text { coastal waters, } \\
\text { QD }\end{array}$ & $\begin{array}{c}\text { coastal waters, } \\
\text { QD }\end{array}$ & $\begin{array}{c}\text { maricultural } \\
\text { waters, ZJ }\end{array}$ & $\begin{array}{l}\text { molluscan culture } \\
\text { pond, QD }\end{array}$ & $\begin{array}{l}\text { molluscan culture } \\
\text { pond, QD }\end{array}$ & $\begin{array}{l}\text { mariculture } \\
\text { waters, ZJ }\end{array}$ \\
\hline $\begin{array}{l}\text { Body size in vivo } \\
(\mu \mathrm{m})\end{array}$ & $30-55 \times 10-15$ & $45-65 \times 15-25$ & $30-45 \times 10-12$ & $35-40 \times 20-25$ & $30-50 \times 10-20$ & $30-50 \times 10-20$ & $25-30 \times 10-15$ \\
\hline $\begin{array}{l}\text { Somatic kineties } \\
\text { (no.) }\end{array}$ & 11 or 12 & 10 or 11 & 11 or 12 & 12 & 10 & 10 or 11 & 10 \\
\hline $\begin{array}{l}\text { Buccal length/ } \\
\text { body length (\%) }\end{array}$ & $25-33$ & 30 & $40-50$ & 40 & 40 & $35-40$ & $40-50$ \\
\hline Extrusome & not observed & not observed & present & present & not observed & not observed & present \\
\hline Data source & $\begin{array}{l}\text { Song \& Wilbert } \\
\text { (2000) }\end{array}$ & present study & $\begin{array}{l}\text { Song et al. } \\
\text { (2002) }\end{array}$ & present study & $\begin{array}{l}\text { Song \& Wilbert } \\
\text { (2000) }\end{array}$ & $\begin{array}{l}\text { Ma \& Song } \\
\text { (2003) }\end{array}$ & present study \\
\hline
\end{tabular}

\section{Metanophrys similis Song et al., 2002}

The Zhanjiang population is identical to the original description (Song et al. 2002) according to the body size, ciliature and habitat; hence, the identity of this species is not in doubt. Compared with the original description, the population described in this paper has a different body shape (plump pyriform vs. slender body shape in Song et al. 2002; Table 3), which may be due to different nutritional conditions (Song et al. 2002).

\section{Acknowledgments}

This work was supported by the Natural Science Foundation of China (project numbers: 31471973 , 31501844, 31470064). The authors extend their sincere appreciation to the Deanship of Scientific Research at King Saud University for its funding of this Prolific Research Group (PRG-1436-24). Many thanks are given to the reviewers for their helpful suggestions to this manuscript.

\section{References}

Agatha S., Spindler M. \& Wilbert N. 1993. Ciliated protozoa (Ciliophora) from Arctic sea ice. Acta Protozoologica 32: 261-268.

Aescht E. 2001. Catalogue of the Generic Names of Ciliates (Protozoa, Ciliophora). Biologiezentrum des Oberösterreichischen Landesmuseum, Linz, Austria.

Borror A.C. 1963. Morphology and ecology of some uncommon ciliates from Alligator Harbor, Florida. Transactions of the American Microscopical Society 82: 125-131. http://dx.doi.org/10.2307/3223987

Budiño B., Lamas J., Pata M., Arranz J., Sanmartín M.L. \& Leiro J. 2011. Intraspecific variability in several isolates of Philasterides dicentrarchi (syn. Miamiensis avidus), a scuticociliate parasite of farmed turbot. Veterinary Parasitology 175: 260-272. http://dx.doi.org/doi:10.1016/j.vetpar.2010.10.011

Castro L.A., Küppers G.C., Schweikert M., Harada M.L. \& Paiva T.S. 2014. Ciliates from eutrophized water in the northern Brazil and morphology of Cristigera hammeri Wilbert, 1986 (Ciliophora, Scuticociliatia). European Journal of Protistology 50: 122-133. http://dx.doi.org/10.1016/j. ejop.2014.01.005 
PAN X. et al., Descriptions of four marine scuticociliates

Cawthorn R.J., Lynn D.H., Despres B., MacMillan R., Maloney R., Loughlin M. \& Bayer R. 1996. Description of Anophryoides haemophila n. sp. (Scuticociliatida: Orchitophryidae), a pathogen of American lobsters Homarus americanus. Diseases of Aquatic Organisms 24: 143-148. http://dx.doi. org/10.3354/dao024143

Fan X., Miao M., Al-Rasheid K.A.S. \& Song W. 2009. A new genus of marine scuticociliate (Protozoa, Ciliophora) from northern China, with a brief note on its phylogenetic position inferred from small subunit ribosomal DNA sequence data. Journal of Eukaryotic Microbiology 56: 577-582. http://dx.doi. org/10.1111/j.1550-7408.2009.00436.x

Fan X., Chen X., Song W., Al-Rasheid K.A.S. \& Warren A. 2010. Two new marine scuticociliates, Sathrophilus planus n. sp. and Pseudoplatynematum dengi n. sp., with improved definition of Pseudoplatynematum (Ciliophora, Oligohymenophora). European Journal of Protistology 46: 212-220. http://dx.doi.org/10.1016/j.ejop.2010.03.002

Fan X., Hu X., Al-Farraj S.A., Clamp J.C. \& Song W. 2011a. Morphological description of three marine ciliates (Ciliophora, Scuticociliatia), with establishment of a new genus and two new species. European Journal of Protistology 47: 186-196. http://dx.doi.org/10.1016/j.ejop.2011.04.001

Fan X., Lin X., Al-Rasheid K.A.S., Al-Farraj S.A., Warren A. \& Song W. 2011b. The diversity of scuticociliates (Protozoa, Ciliophora): a report on eight marine forms found in coastal waters of China, with a description of one new species. Acta Protozoologica 50: 219-234. http://dx.doi.org/10.4467/168 90027AP.11.021.0021

Fan X., Al-Farraj S.A., Gao F. \& Gu F. 2014. Morphological reports on two species of Dexiotricha (Ciliophora, Scuticociliatia), with a note on the phylogenetic position of the genus. International Journal of Systematic and Evolutionary Microbiology 64: 680-688. http://dx.doi.org/10.1099/ijs.0.059899-0

Foissner W. \& Wilbert N. 1981. A comparative study of the infraciliature and silverline system of the freshwater scuticociliates Pseudocohnilembus putrinus (Kahl, 1928) nov. comb., P. pusillus (Quennerstedt, 1869) nov. comb., and the marine form P. marinus Thompson, 1966. Journal of Protozoology 28: 291297. http://dx.doi.org/10.1111/j.1550-7408.1981.tb02853.x

Foissner W., Jung J.H., Filker S., Rudolph J. \& Stoeck T. 2014. Morphology, ontogenesis and molecular phylogeny of Platynematum salinarum nov. spec., a new scuticociliate (Ciliophora, Scuticociliatia) from a solar saltern. European Journal of Protistology 50: 174-184. http://dx.doi.org/10.1016/j. ejop.2013.10.001

Gao F., Fan X., Yi Z., Strüder-Kypke M. \& Song W. 2010. Phylogenetic consideration of two scuticociliate genera, Philasterides and Boveria (Protozoa, Ciliophora) based on 18S rRNA gene sequences. Parasitology International 59: 549-555. http://dx.doi.org/10.1016/j.parint.2010.07.002

Gao F., Katz L.A. \& Song W. 2012a. Insights into the phylogenetic and taxonomy of philasterid ciliates (Protozoa, Ciliophora, Scuticociliatia) based on analyses of multiple molecular markers. Molecular Phylogenetics and Evolution 64: 308-317. http://dx.doi.org/10.1016/j.ympev.2012.04.008

Gao F., Strüder-Kypke M., Yi Z., Miao M., Al-Farraj S.A. \& Song W. 2012b. Phylogenetic analysis and taxonomic distinction of six genera of pathogenic scuticociliates (Protozoa, Ciliophora) inferred from small-subunit rRNA gene sequences. International Journal of Systematic and Evolutionary Microbiology 62: 246-256. http://dx.doi.org/10.1099/ijs.0.028464-0

Gao F., Katz L.A. \& Song W. 2013. Multigene-based analyses on evolutionary phylogeny of two controversial ciliate orders: Pleuronematida and Loxocephalida (Protista, Ciliophora, 
Oligohymenophorea). Molecular Phylogenetics and Evolution 68: 55-63. http://dx.doi.org/10.1016/j. ympev.2013.03.018

Grolière C.A. \& Léglise M. 1977. Paranophrys carcini n. sp., Cilié Philasterina récolté dans l'hémolymphe du crabe Cancer pagurus Linné. Protistologica 13: 503-507.

Lynn D.H. 2008. The Ciliated Protozoa. Characterization, Classification and Guide to the Literature. Springer Verlag, Dordrecht.

Lynn D.H. \& Strüder-Kypke M. 2005. Scuticociliate endosymbionts of echinoids (phylum Echinodermata): phylogenetic relationships among species in the genera Entodiscus, Plagiopyliella, Thyrophylax, and Entorhipidium (phylum Ciliophora). The Journal of Parasitology 91: 1190-1199. http://dx.doi.org/10.1645/GE-445R.1

Ma H. \& Song W. 2003. Stomatogenesis of the marine ciliate Metanophrys sinensis (Protozoa: Ciliophora: Scuticociliatida). Journal of the Marine Biological of Association of the United Kingdom 83: 407-410. http://dx.doi.org/10.1017/S0025315403007252h

Mallo N., Lamas J., Piazzon C. \& Leiro J.M. 2014. Presence of a plant-like proton-translocating pyrophosphatase in a scuticociliate parasite and its role as a possible drug target. Parasitology 142: 449-462. http://dx.doi.org/10.1017/S0031182014001267

Noland L.E. 1937. Observations on marine ciliates of the Gulf Coast of Florida. Transactions of the American Microscopical Society 56: 160-171. http://dx.doi.org/10.2307/3222944

Ofelio C., Blanco A., Roura Á., Pintado J., Pascual S. \& Planas M. 2014. Isolation and molecular identification of the scuticociliate Porpostoma notata Moebius, 1888 from moribund reared Hippocampus hippocampus (L.) seahorses, by amplification of the SSU rRNA gene sequences. Journal of Fish Diseases 37: 1061-1065. http://dx.doi.org/10.1111/jfd.12207

Pan H., Huang J., Hu X., Fan X., Al-Rasheid K.A.S. \& Song W. 2010. Morphology and SSU rRNA gene sequences of three marine ciliates from Yellow Sea, China, including one new species, Uronema heteromarinum nov. spec. (Ciliophora, Scuticociliatida). Acta Protozoologica 49: 45-49.

Pan X., Shao C., Ma H., Fan X., Al-Rasheid K.A.S., Al-Farraj S.A. \& Hu X. 2011. Redescriptions of two marine scuticociliates from China, with notes on stomatogenesis in Parauronema longum (Ciliophora, Scuticociliatida). Acta Protozoologica 50: 301-310. http://dx.doi.org/10.4467/16890027 $\underline{\text { AP.11.027.0064 }}$

Pan X., Bourland W.A. \& Song W. 2013a. Protargol synthesis: An in-house protocol. Journal of Eukaryotic Microbiology 60: 609-614. http://dx.doi.org/10.1111/jeu.12067

Pan X., Gao F., Liu W., Fan X., Warren A. \& Song W. 2013b. Morphology and SSU rRNA gene sequences of three Frontonia species, including a description of F. subtropica spec. nov. (Ciliophora, Peniculida). European Journal of Protistology 49: 67-77. http://dx.doi.org/10.1016/j.ejop.2012.05.002

Pan X., Huang J., Fan X., Ma H., Al-Rasheid K.A.S., Miao M. \& Gao F. 2015a. Morphology and phylogeny of four marine scuticociliates (Protista, Ciliophora), with descriptions of two new species: Pleuronema elegans spec. nov. and Uronema orientalis spec. nov. Acta Protozoologica 54: 31-43. http://dx.doi.org/10.4467/16890027AP.15.003.2190

Pan X., Yi Z., Li J., Ma H., Al-Farraj S.A. \& Al-Rasheid K.A.S. 2015b. Biodiversity of marine scuticociliates (Protozoa, Ciliophora) from China: description of seven morphotypes including a new species, Philaster sinensis spec. nov. European Journal of Protistology 51: 142-157. http://dx.doi. org/10.1016/j.ejop.2015.02.005 
PAN X. et al., Descriptions of four marine scuticociliates

Pérez-Uz B. \& Song W. 1995. Uronema gallicum sp. n. (Protozoa: Ciliophora) a new marine scuticociliate from the coastal area of Calais. Acta Protozoologica 34: 143-149.

Small E.B. \& Lynn D.H. 1985. Phylum Ciliophora Doflein, 1901. In: Lee J.J., Hunter S.H. \& Bovee E.C. (eds) An Illustrated Guide to the Protozoa: 393-575. Society of Protozoologists, Lawrence, Kansas.

Song W. 2000. Morphological and taxonomical studies on some marine scuticociliates from China Sea, with description of two new species, Philasterides armatalis sp. n. and Cyclidium varibonneti sp. $\mathrm{n}$. (Protozoa: Ciliophora: Scuticociliatida). Acta Protozoologica 39: 295-322.

Song W. \& Wilbert N. 2000. Redefinition and redescription of some marine scuticociliates from China, with report of a new species, Metanophrys sinensis nov. spec. (Ciliophora, Scuticociliatida). Zoologischer Anzeiger 239: 45-74.

Song W. \& Wilbert N. 2002. Reinvestigations of three "well-known" marine scuticociliates: Uronemella filificum (Kahl, 1931) nov. gen., nov. comb., Pseudocohnilembus hargisi Evans \& Thompson, 1964 and Cyclidium citrullus Cohn 1865, with description of the new genus Uronemella (Protozoa, Ciliophora, Scuticociliatida). Zoologischer Anzeiger 241: 317-331. http://dx.doi.org/10.1078/0044-5231-00075

Song W., Shang H., Chen Z. \& Ma H. 2002. Comparison of some closely-related Metanophrys-taxa with description of a new species Metanophrys similis nov. spec. (Ciliophora, Scuticociliatida). European Journal of Protistology 38: 45-53. http://dx.doi.org/10.1078/0932-4739-00848

Song W., Zhao Y., Xu K., Hu X. \& Gong J. 2003. Pathogenic Protozoa in Mariculture. Science Press, Beijing.

Song W., Warren A. \& Hu X. 2009. Free-living Ciliates in Bohai and Yellow Sea, China. Science Press, Beijing.

Strüder M. \& Wilbert N. 1992. Contribution to the taxonomy of the family Paranophryidae Jankowski in Small \& Lynn, 1985. Acta Protozoologica 31: 33-37.

Thompson Jr. J.C. 1964. A redescription of Uronema marinum, and a proposed new family Uronematidae. The Virginia Journal of Science 15: 80-87.

Thompson Jr. J.C. \& Kaneshiro E.S. 1968. Redescriptions of Uronema filificum and U. elegans. Journal of Protozoology 15: 141-144. http://dx.doi.org/10.1111/j.1550-7408.1968.tb02099.x

Wang Y., Hu X., Long H., Al-Rasheid K.A.S., Al-Farraj S. \& Song W. 2008a. Morphological studies indicate that Pleuronema grolierei nov. spec. and P. coronatum Kent, 1881 represent different sections of the genus Pleuronema (Ciliophora: Scuticociliatida). European Journal of Protistology 44: 131-140. http://dx.doi.org/10.1016/j.ejop.2007.08.008

Wang Y., Song W., Hu X., Warren A., Chen X. \& Al-Rasheid K.A.S. 2008b. Descriptions of two new marine species of Pleuronema, P. czapikae sp. n. and P. wiackowskii sp. n. (Ciliophora: Scuticociliatida), from the Yellow Sea, North China. Acta Protozoologica 47: 35-45.

Wang Y., Song W., Warren A., Al-Rasheid K.A.S., Al-Quraishy S., Al-Farraj S.A., Hu X. \& Pan H. 2009. Descriptions of two new marine scuticociliates, Pleuronema sinica n. sp. and P. wilberti n. sp. (Ciliophora: Scuticociliatida), from the Yellow Sea, China. European Journal of Protistology 45: 29-37. http://dx.doi.org/10.1016/j.ejop.2008.06.001

Wilbert N. \& Song W. 2008. A further study on littoral ciliates (Protozoa, Ciliophora) near King George Island, Antarctica, with description of a new genus and seven new species. Journal of Natural History 42: 979-1012. http://dx.doi.org/10.1080/00222930701877540 
Zhan Z., Stoeck T., Dunthorn M. \& Xu K. 2014. Identification of the pathogenic ciliate Pseudocohnilembus persalinus (Oligohymenophorea: Scuticociliatia) by fluorescence in situ hybridization. European Journal of Protistology 50: 16-24. http://dx.doi.org/10.1016/j.ejop.2013.09.004

Submitted: 30 September 2015

Accepted: 2 January 2016

Published: 18 April 2016

Topic editor: Rudy Jocqué

Desk editor: Danny Eibye-Jacobsen

Printed versions of all papers are also deposited in the libraries of the institutes that are members of the EJT consortium: Muséum national d'Histoire naturelle, Paris, France; Botanic Garden Meise, Belgium; Royal Museum for Central Africa, Tervuren, Belgium; Natural History Museum, London, United Kingdom; Royal Belgian Institute of Natural Sciences, Brussels, Belgium; Natural History Museum of Denmark, Copenhagen, Denmark. 